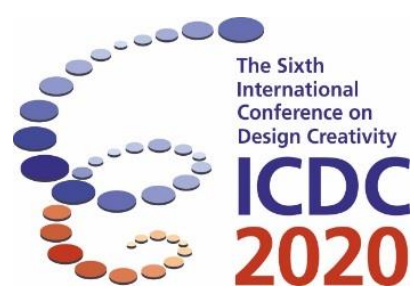

\title{
Teaching creative design and systematic creativity: overview and case study
}

\author{
Iuliia Shnai, Anastasia Chakir and Leonid Chechurin
}

\section{LUT University, Lappeenranta, Finland}

\begin{abstract}
The growth of eLearning technologies seriously outpaces the research-based recommendation on how to apply these tools for predictable and effective results. The emerging education technologies provide an opportunity for teaching improvement. This research refers to the teaching in the field of creative design. The study helps to understand which education innovative teaching methods and learning strategies are used for teaching creative design and specifically TRIZ. The aim of this paper is to overview the innovative teaching methods for creative design and education technologies used for its teaching. The study overviews the most influential cases of creative design teaching and introduces online and digital teaching approaches based on the case study in LUT University. The learning environments for the course of "Systematic Creativity and TRIZ" are described. The review demonstrated that the most influential approaches to teaching creativity are problem solving and collaborative learning with limited technology implementation and description. The experience of teaching demonstrates that flipped classroom setup increases the engagement measured by students' high video views and involvement in the class.
\end{abstract}

Keywords: Creative Design, Systematic Creativity, TRIZ, Teaching, Education Technology; Flipped Classroom

\section{Introduction}

Soft skills attract special attention in the academic and corporate learning. Problem-solving, communication and creativity skills are among the most successfully targeted soft skills in flipped learning model (Baytiyeh, 2017). Creativity or creative thinking is in the spotlight nowadays (Wei et al., 2015). However, instructors have to overcome the same challenge and find the way to develop creative skills in students. The same question becomes the main concern if the subject is creative design, invention and innovation.

Digital transformation of the world requires new soft skills from students. Teaching methods are changing slowly, making it hard to obtain and practice these skills in the class. The universities and teachers face a number of challenges which are similar to different fields including teaching creative design (CEPHEI, 2019). Firstly, there is a demand for reality-based education that satisfies the needs of future employers. Together with the emerging specialties, here also comes the necessity to develop the soft skills required by employers. Secondly, a boost in digital technologies has a considerable impact on education. While universities mainly continue using traditional teaching approaches, supported by traditions technologies, the life outside of academia adopts advanced ways of doing things. Reflecting 
these trends, universities are aiming to create digital project-based learning that reflects industrial and societal needs.

This research provides a basic overview of teaching methods and instruments used to teach creative design, creative tasks and systematic creativity. The creativity is narrowed in this paper to creative design and systematic creativity. The focus of the paper is teaching algorithmic creativity, which leads to engineering and design invention. In addition, to solve highlighted problems the advanced digital and active teaching methods are described as a part of the case study in LUT University.

\section{Background}

Teaching of creative or conceptual design can be performed by a variety of tools. Alongside with that the different innovative teaching methods and educational technologies enable the improvement of the teaching. Therefore, the same creative design tools can be taught differently depending on the learning strategies and teaching design process.

To represent and justify the educational designs technological pedagogical and content knowledge (TPCK) framework was followed (Mishra \& Koehler, 2006). Each part of the TPCK framework defines and testifies the elements of teaching process and interactions between them (Figure. 1.). According to it, creativity and creative design course teachers should know more than creative design tools. They should also find the most effective way for students to develop knowledge and skills. Therefore, teachers need to overview the pedagogical perspective of the teaching, such as teaching methods and educational technology.

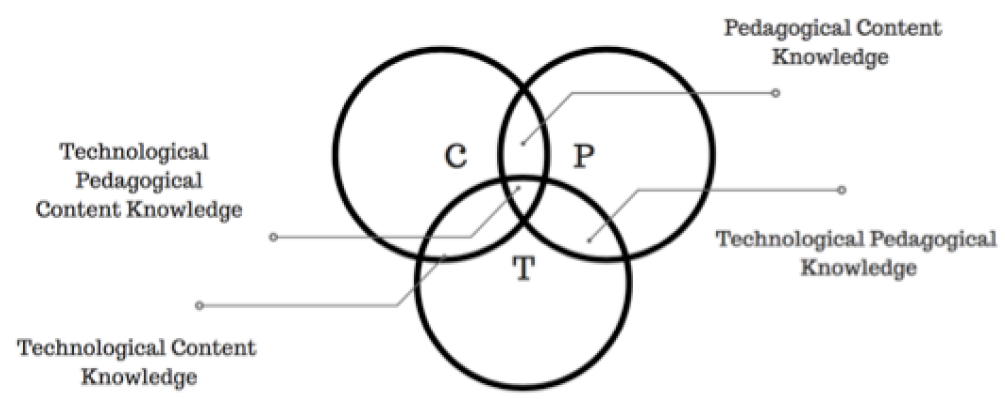

Figure 1. TPCK model (Mishra.P, J. Koehler (2006)

\subsection{Creative Design tools}

Creative design tools aim to provide the ability to generate ideas on demand. It is a part of the product design process, which refers to conceptual design stage. A large number of different tools have been developed, revealing the different levels of practical or scientific application. Among these tools are Brainstorming, Design Thinking, TRIZ, S-C theory, 6 Sigma, Lean, Axiomatic design, DFMA and many others. The toolkit can be divided into two branches. The first branch refers to easy to use tools, for instance Brainstorming, which does not require any background knowledge, easily applied to any field and has a heuristic background. This group of tools doesn't provide a detailed systematic solution. The second branch provides more systematic structural well-developed solutions, for example, TRIZ, Axiomatic design. However, it requires background knowledge in the domain of the problem, for most engineering problems in physics, chemistry, engineering as well as the discipline in thinking: systematic and logic based (Tour; 2012; Ilevbar et al., 2013). TRIZ is a toolkit for systematic ideas generation and inventing. It is a cost-effective mechanism for engineering troubleshooting and new product development (Ilevbare et al., 2013). Having found it way to academic teaching, TRIZ has also a significant record in industry, as a field design tool and the subject for corporate skills uplift for employees. 


\subsection{Teaching methods and education technology}

The whole educational path can be described with the model 70:20:10 (Docedo, 2016). According to the research, only $10 \%$ of learning activity refers to traditional teaching through face-to-face and online classes and courses (Docedo, 2016). While 70\% happens at the workplace or in real life through tasks and problem-solving. The rest $20 \%$ is gained by observing others, teamwork and feedback system. Thus, companies demand a reality or project-based learning with fastly delivered knowledge, for instance via online.

Education technologies have a huge potential to support the student-centered teaching approaches. Teacher-centered approaches in the form of passive lecturing step back giving way to more adaptable learning which focuses on students. Cultural shift roots from professors minds, where lecturer is not any more «sage on the stage» but rather «guide on the side» (Gilboy et al., 2015). Teachers role shifts to being guide or mentor on the way of student learning. Flexible, adaptable reality-based education better fits millennials needs specifically for higher education. Among these educational methods are collaborative learning, problems solving and other methods which can be a part of Hackathons, Flipped classes, Online courses and other educational designs. Thereby, students find digital teaching approaches extremely helpful (McGrawHill, 2019). Lecture as the essential and integral component of traditional learning becomes more insufficient in achieving effective results in class performance alongside with available digital methods. Student attention after 10 minutes of an unvarying narration significantly declines (Hartley, 1976; MacManaway, 1976). In addition, students have higher engagement on short video episodes between 0-3 minutes and that in longer videos top engagement is at 6 minutes (Guo, 2014). Lecture transits to the short micro-videos or texts comprising such digital and mixed methods like online, blended learning, flipped classroom, microlearning, and others.

As education technologies are constantly changing, they are specifically challenging for teachers. It requires teachers not only to obtain new knowledge on the research or teaching field but also in arising technologies. For example, augmented reality (AR) is one of the promising education technologies. However, teachers have a limited interest to and knowledge in AR technology and how to teach with it (Wei et al., 2015), At the same time, there are a number of challenges associated with this technology: technological, pedagogical and learning (Wu et al., 2013). To ease the process of technologies adaptation for teachers, the developed teaching methodologies should be scaled within specific fields. According to multiple studies, group activities, especially during the training process, greatly affect the quality of the learning process and refer to more constructive learning and scaffolding in the class (Davies et al., 2013; Mok, 2014; Enfield, 2013) which comes alongside with the idea generation process.

\section{Methodology and goals}

To explore the topic of creativity teaching via innovative methods two primarily methods were used: systematic literature review and case study. To conduct the literature review double-blind review papers from the Scopus database were extracted. The keywords used are "Systematic creativity" AND "Teaching", "Creative design" AND "Teaching". Overall 191 papers were found for these keywords. The selected articles were analysed by abstract. It was found that the majority of papers are not relevant for the study, as they neither focus on creativity as course subject nor explore innovative approaches to teaching. Therefore $70 \%$ of the papers were excluded on this stage. The most cited and relevant case studies were chosen for full-text analyses out of which 7 were rigorously overviewed in this research. The paper contributes to the research in the field by presenting the case study of the systematic creativity course taught in the LUT university. The case study elaborates the different teaching methods of Systematic Creativity and TRIZ course. Each teaching method or instrument refers primarily to different teaching approaches and secondary to the TRIZ methods.

The main goals of the research are:

- to overview the existing learning strategies and teaching methods for teaching Creative Design, Innovation and Systematic Creativity;

- to reveal the application of educational technologies to these methods; 
- to observe the application and adaptation of the specific teaching methods based on case study for the course "Systematic Creativity and TRIZ".

\section{Results}

This part reviews the existing innovative teaching approaches taking the influential cases in terms of citations. In addition the part is extended by the description of the case study.

\subsection{Creative Design Teaching Review}

Among the technologies used for teaching creative design can be AR. Wei et al. (2015) introduce ARbased approach of teaching for Chinese students, creating virtual learning environments. It shows that AR improves significantly learning motivation and creativity of students measured by the assessment conducted among students and comparison of designs with and without AR. The other learning environment is a completely online space "Second life" which is literally a space where you can build your second life but virtually. It is the virtual environments which are used for teaching and learning within the classrooms (Keskitalo, 2011). However, the online environment of the approach demands more concentration and time from instructors.

The teaching of concept-knowledge collaboratively has many advantages, in particular, it helps students to see their thinking inertia and fixation and overcome this state (Hatchuel, 2011). Case study conducted by Doppelt (2009) indicated that creative thinking skills are provoked through documentation of the process. Penaluna et al. (2010) provide the concept which challenges the systematic and algorithmic approaches to invention and design thinking. Free time is a thinking time, which gives an opportunity to extend the understanding and then to improve the thinking.

Following, the pedagogical contained framework introduced in the background and goals of the papers the Table 1 was formed. To ensure the quality of educational design three components and their interconnections should be analysed. The first component is pedagogy, which is described in the papers by the teaching method used. Creative design tools are the content, which courses are providing and education technology is a used technology. Therefore, we observe the educational design described from three core perspectives to extend the systematise and make different courses designs comparable. Results justify the effectiveness in terms of the learning outcomes of the conducted courses. The results in the Table 1 represent a short summary of the main learning outcomes described and analysed in the papers respectively.

\subsection{Systematic Creativity and TRIZ course case study}

The research utilities a case study based on Systematic creativity and TRIZ course at LUT University. Pioneered in 2011, the course was taught in traditional form . Currently, the course has two forms in terms of duration: intensive and standard. An intensive course is launched twice a year during Winter and Summer schools and equivalent to 78 hours workload. The workload of the standard course is equivalent to 156 hours. Moreover, two teaching approaches are utilised to teach the course: online and flipped.

From 2011 to 2015, there were no significant changes in course design in terms of structure. The first attempt to re-arrange course was within the Summer school intensive course in 2016. The target was flipped classroom design, where the in-class time is devoted to activities and pure lecture is substituted with digital preparation materials, mainly videos. Course instructors integrated the number of teaching methods and techniques to promote creativity and inventing process. The primary creativity design toolkit was TRIZ. The primary technology and external resources are described in table 2 . The evaluation and results column describes what was revealed.

Similar to the previous table, Table 2 describes different educational designs, however, applied to one course. Course time column refers to the year(s) when the certain learning environment was tested. Teaching methods and techniques together with evaluation column are available due to the extended information about the course, which was not possible to obtain from the papers analysed in Table 1.

The initial and most simple Learning environment which was used is video hosting, through which only videos were delivered. The second learning environment set up the flipped classroom where the videos 
with questions inside were delivered before the class virtually and in class time was dedicated to activities. The third active learning environment enables to generate ideas in the class from their personal laptops in collaborative space. The fourth learning environments refer to full learning management systems where online and flipped courses are hosted. The lastly set up learning environment provides the opportunity to self-study.

Table 1. Teaching creative design methods

\begin{tabular}{|c|c|c|c|c|c|}
\hline № & Author & Teaching methods & $\begin{array}{c}\text { Creative } \\
\text { Design tools }\end{array}$ & $\begin{array}{l}\text { Education } \\
\text { Technology }\end{array}$ & Results \\
\hline 1 & $\begin{array}{l}\text { Wei et al. } \\
\text { (2015) }\end{array}$ & $\begin{array}{l}\text { AR based Scheme } \\
\text { Virtual Reality }\end{array}$ & Creative design & AR & $\begin{array}{l}\text { Increase motivation and } \\
\text { creativity design }\end{array}$ \\
\hline 2 & $\begin{array}{l}\text { Hatchuel } \\
\text { (2011) }\end{array}$ & $\begin{array}{l}\text { Collaborative, } \\
\text { project-based } \\
\text { learning }\end{array}$ & $\begin{array}{l}\text { Concept- } \\
\text { knowledge } \\
\text { theory }\end{array}$ & $\begin{array}{l}\text { Joint } \\
\text { educational } \\
\text { program }\end{array}$ & $\begin{array}{l}\text { Boost in generation of } \\
\text { alternatives, knowledge } \\
\text { acquisition, collective } \\
\text { creativity and creative } \\
\text { process }\end{array}$ \\
\hline 3 & $\begin{array}{l}\text { Doppelt } \\
(2009)\end{array}$ & Portfolio & $\begin{array}{l}\text { Authentic } \\
\text { projects (in } \\
\text { mechatronics) }\end{array}$ & - & $\begin{array}{c}\text { Various levels of creative } \\
\text { thinking. } \\
\text { Documentation skills. }\end{array}$ \\
\hline 4 & $\begin{array}{l}\text { Keskitalo } \\
\text { (2011) }\end{array}$ & $\begin{array}{c}\text { Meaningful learning; } \\
\text { Collaborative } \\
\text { learning; } \\
\text { Online/ Virtual } \\
\text { environments; }\end{array}$ & $\begin{array}{c}\text { Creative design } \\
\text { task }\end{array}$ & Second Life & $\begin{array}{l}\text { Environment supported the } \\
\text { characteristics of } \\
\text { meaningful learning. }\end{array}$ \\
\hline 5 & $\begin{array}{l}\text { Lenzholzer } \\
\text { and Brown } \\
\quad(2013)\end{array}$ & Problem-Solving & $\begin{array}{c}\text { Creative design } \\
\text { task in } \\
\text { environmental } \\
\text { field (Methods) } \\
\text { of } 3 \text { steps }\end{array}$ & - & $\begin{array}{c}\text { Increased students' } \\
\text { engagement and unexpected } \\
\text { insights }\end{array}$ \\
\hline 6 & $\begin{array}{l}\text { Penaluna et } \\
\text { al. (2010) }\end{array}$ & $\begin{array}{c}\text { Cultural } \\
\text { environments and } \\
\text { non algorithmic } \\
\text { teaching practises. } \\
\text { Creative curriculum }\end{array}$ & - & - & $\begin{array}{l}\text { Creative entrepreneurial } \\
\text { curriculum facilitate to out- } \\
\text { of box thinking }\end{array}$ \\
\hline 7 & $\begin{array}{l}\text { Emmanuel } \\
\text { et al. (2010) }\end{array}$ & Open tasks & $\begin{array}{c}\text { Medical } \\
\text { wearable mask } \\
\text { design }\end{array}$ & & $\begin{array}{l}\text { Increase engagement on } \\
\text { personal level. }\end{array}$ \\
\hline
\end{tabular}

During the course transformation, different types of feedback were gathered and rigorously analysed in the previous research. This study focuses on presenting and justifying the Systematic Creativity and TRIZ course transformation within the selected framework to compare with the studies analysed in the literature review section. The findings show the overall growing involvement in the course, measured by the high amount of views and higher respondents rates. In addition, video views are much lower if there is no element of control, like quizzes (LE1). Comparing videos with integrated quizzes (LE2) in it and videos with the quizzes going after, the video viewing percentage is much lower. In general, students engage more in shorter videos (Khan, 2019). 


\section{Discussion and conclusion}

This study presents the initial overview of the innovative education designs for the creative design and systematic creativity subjects. It was observed that the collaborative learning and problem-based learning teaching methods are prevailing in the most relevant and cited literature in the field. The problem-solving was not just a part of the "Systematic Creativity and TRIZ" course, but its core. In traditional form lectures are mixed with given in the class small problems and course includes final project. In the flipped form more time is spent on activities and problems of different kind like idea generation (LE-3). In the fully online form of the TRIZ course, the problems are presented in the form of games, like Jeopardy. Therefore, among teaching approaches there is an alignment in the literature and in the case study.

Table 2. Systematic Creativity and TRIZ case

\begin{tabular}{|c|c|c|c|c|}
\hline $\begin{array}{c}\text { Course } \\
\text { time }\end{array}$ & $\begin{array}{c}\text { Environment } \\
\text { s }\end{array}$ & $\begin{array}{c}\text { Teaching methods/ } \\
\text { techniques }\end{array}$ & $\begin{array}{c}\text { Education } \\
\text { Technology }\end{array}$ & Evaluation \& Results \\
\hline 2016 & $\begin{array}{c}\text { LE1- Video } \\
\text { Learning } \\
\text { Environments } \\
\text { (online) }\end{array}$ & $\begin{array}{c}\text { Video delivery. } \\
\text { Knowledge delivery }\end{array}$ & $\begin{array}{c}\text { YouTube (For } \\
\text { video hosting) }\end{array}$ & $\begin{array}{c}\text { Video views decline } \\
\text { significantly after 3 minutes. It } \\
\text { was studied how video duration } \\
\text { impact on student engagement. }\end{array}$ \\
\hline 2017 & $\begin{array}{c}\text { LE2- Video } \\
\text { \& Quizzes } \\
\text { (online) }\end{array}$ & $\begin{array}{c}\text { Which delivers videos } \\
\text { combined with the } \\
\text { questions and comments. } \\
\text { It was part of Flipped } \\
\text { classroom design. }\end{array}$ & the EdPuzzle & $\begin{array}{c}\text { The high level of views show } \\
\text { the high engagement. } \\
\text { It was studied how the views } \\
\text { impact on student engagement. }\end{array}$ \\
\hline 2018 & $\begin{array}{c}\text { LE3- Activity } \\
\text { learning } \\
\text { environment } \\
\text { virtually-in } \\
\text { class) }\end{array}$ & $\begin{array}{c}\text { Online Idea Generation } \\
\text { Activity }\end{array}$ & $\begin{array}{c}\text { Facebook, Social } \\
\text { learning }\end{array}$ & $\begin{array}{c}\text { There was no clear evidence } \\
\text { that students generate more } \\
\text { ideas after learning TRIZ but } \\
\text { they generate higher quality } \\
\text { ideas. }\end{array}$ \\
\hline $\begin{array}{c}\text { LE4- } \\
\text { ongoing }\end{array}$ & $\begin{array}{c}\text { Learning } \\
\text { management } \\
\text { system } \\
\text { (online) }\end{array}$ & $\begin{array}{c}\text { Flipped Classroom } \\
\text { design was delivered } \\
\text { fully. } \\
\text { Knowledge and skills } \\
\text { development. Problem } \\
\text { Solving and final project } \\
\text { in the class. }\end{array}$ & $\begin{array}{c}\text { Open Learning } \\
\text { Management } \\
\text { System } \\
\text { (Thinkific), Video } \\
\text { development } \\
\text { instruments, } \\
\text { Content Hosting }\end{array}$ & $\begin{array}{c}\text { Students are more engaged. } \\
\text { Measured by high amount of } \\
\text { views, and high response rate. } \\
\text { However, satisfaction in some } \\
\text { courses decreases. }\end{array}$ \\
\hline $\begin{array}{c}\text { 2019- } \\
\text { ongoing }\end{array}$ & $\begin{array}{c}\text { LE5- Self } \\
\text { Paced } \\
\text { (online) }\end{array}$ & $\begin{array}{c}\text { Self- Paced online } \\
\text { learning. Knowledge } \\
\text { delivery and knowledge } \\
\text { check extended by } \\
\text { online problems and } \\
\text { exercises to solve. }\end{array}$ & $\begin{array}{c}\text { Opendx, CEPHEI } \\
\text { platform, Amazon } \\
\text { hosting }\end{array}$ & $\begin{array}{c}\text { The activity such as } \\
\text { performance will be measured. } \\
\text { Results are not yet obtained. } \\
\text { The amount of views and } \\
\text { answers on quiz will be } \\
\text { measured. }\end{array}$ \\
\hline
\end{tabular}

From the content perspective, all systematized papers refer to the creative design, and none of them to systematic creativity. However, the content of analysed creative design courses refer to the conceptual design stage. And the TRIZ course also refers to it.

However, the educational technology in the literature (Table 1) was mentioned only for the 3 papers among 7 . The other papers either, do not use any of technology or do not find relevant to mention it. It shows still lack of the high quality research related to innovative and digital methods for teaching systematic creativity and creative design. It underlines the significance of the case study conducted 
based on the course of Systematic-Creativity and TRIZ. In addition, the elaboration of the study in the number of research papers, Master Thesis and even PhD work underlines the sophistication of the research.

The next step of the research is to rigorously analyse the rest of the most relevant papers from extracted 191, which will be approximately 40-50 papers. In addition, the categorisation of the creative design stages which are taught will be presented.

Transferring the idea that "creative thinking should be taught using creative approaches" the basic teaching methods, learning strategies and environments. It was found that there are different cases and innovative teaching approaches which are not yet scalable and appear in the bottom-up approach in the field of creative design. Therefore any collaborations between professionals in the field to share their experience of improved, innovative, digital teaching of well known creative design tools could be relevant.

The current study provides a brief structured overview of the most influential cases of innovative forms of teaching creative design tools. In addition, it extends the literature by the case study made in LUT university within 5 years. The problem-solving and project-based teaching approaches presented in the literature correlates with the case study. However, education technologies are not specified in the literature. This fast should be investigated further for the proper reasoning. However, results presented in the case study provide more narrow research on students satisfaction and engagement, whereas in the literature more diverse parameters are studied and get improved, like students motivation. The casestudy based advice includes providing more problem-solving, collaboration and project based activities. The videos which are shorter and have integrated control elements like quizzes are found to be more engaging. The student satisfaction with the educational designs can vary and can even decrease initially due to adaptation period. Therefore, the assessment and evaluation methods for innovative teaching approaches should be also innovative. The traditional scores and motivation comparison can be extended by measuring the views, discussions activity and some specific problems to solve like idea generation tasks, where amount and quality of ideas is measured. And technology itself provides the opportunity to get more extensive learning analytics.

It is important to admit that technology implementation in education should be driven not by technology itself but by the learning outcomes of students which need to be achieved. The technology is a supporting instruments but not the core. In this case study, the technology like video fully accomplish the purpose and provide engaging and scalable experience and let teach during the long period. The EdPuzzle environment with integrated video supports students engagement in learning process. And online learning platforms are essential for moving teaching in digital space, however it is difficult to say if they satisfy all the needs of learners and teachers, but accomplished their main function.

The study is the first step toward more rigorous literature review of creative design teaching. It could be a guide for other researchers and practitioners who aim to transit their course of creative design or systematic creativity using the innovative teaching approaches and educational technology. It underlines a number of technologies and teaching methods both from the literature and case study. The presented results expose benefits each of the approaches can bring and what to expect. In addition, it explores how to use TPCK framework to justify the educational design.

\section{References}

Baytiyeh, H. 2017. The flipped classroom model: When technology enhances professional skills. The International Journal of Information and Learning Technology, 34(1), pp. 51-62. doi:10.1108/IJILT-07-20160025

CEPHEI. 2019. CEPHEI - Industrial E-learning. [online] Available at: https://www.cephei.eu/en/ [Accessed 5 Jan. 2020].

Davies, R. S., Dean, D. L., \& Ball, N. (2013). Flipping the Classroom and Instructional Technology Integration in a College-Level Information Systems Spreadsheet Course. Education Technology Research and Development, 61, 563-580. http://dx.doi.org/10.1007/s11423-013-9305-6

Docebo, 2016. Elearning market trends and forecast 2017-2021

Doppelt, Y. 2009. Assessing creative thinking in design-based learning. International Journal of Technology and Design Education, 19(1), pp. 55-65. doi:10.1007/s10798-006-9008-y 
Emmanuel, E., Collins, D. \& Carey, M. 2010. My face, a window to communication: Using creative design in learning. Nurse Education Today, 30(8), pp. 720-725. doi:10.1016/j.nedt.2010.01.011

Enfield, J. 2013. Looking at the Impact of the Flipped Classroom Model of Instruction on Undergraduate Multimedia Students at CSUN. TechTrends, 57(6), pp. 14-27. doi:10.1007/s11528-013-0698-1

Gilboy, M.B., Heinerichs, S., \& Pazzaglia, G. Enhancing Student Engagement Using the Flipped Classroom. Journal of Nutrition Education and Behavior, 47 (1), 109 - 114. doi:http://dx.doi.org/10.1016/j.jneb.2014.08.008 (2015).

Guo P., Kim J., Rubin, R. "How Video Production Affects Student Engagement: An Empirical Study of MOOC Videos", Proceedings of First ACM Conference on LearningScale, pp. 41-50, (2014)

Hartley J, Cameron A.. Some observations on the efficiency of lecturing. Educ Rev.1967;20:30-37 (1976)

Hatchuel, A., Le Masson, P. \& Weil, B. 2011. Teaching innovative design reasoning: How concept knowledge theory can help overcome fixation effects. Artificial Intelligence for Engineering Design, Analysis and Manufacturing, 25(1), pp. 77-92. doi:10.1017/S089006041000048X

Ilevbare, I. M., Probert, D. \& Phaal, R. 2013. A review of TRIZ, and its benefits and challenges in practice. Technovation, 33(2-3), pp. 30-37. doi:10.1016/j.technovation.2012.11.003

Khan, A., I. (2019). Data driven decision making in digital education : A case study from Finland and Russia http://urn.fi/URN:NBN:fi-fe2019072323186

Keskitalo, T., Pyykkö, E. \& Ruokamo, H. 2011. Exploring the Meaningful Learning of Students in Second Life. Journal of Educational Technology \& Society, 14(1), pp. 16-26.

Lenzholzer, S. \& Brown, R. 2013. Climate-responsive landscape architecture design education. Journal of Cleaner Production, 61(C), . doi:10.1016/j.jclepro.2012.12.038

MacManaway LA. Teaching methods in higher education — innovation and research. Higher Educ Q.;24:321329 (1970)

McGrawHill, https://www.mheducation.com/highered/explore/studytrends.html, last accessed 2019/05/13

Mishra P, Koehler M (2006) Technological Pedagogical Content Knowledge: A Framework for Teacher Knowledge Teachers College Record Vol 108, Number 6, , pp. 1017-1054

Mok, H. (2014). Teaching tip: The flipped classroom. Journal of Information Systems Education, 25(1), 7-11.

Murgatroyd, S. 2010. 'Wicked Problems' and the Work of the School. European Journal of Education, 45(2), pp. 259-279.

Penaluna, A., Coates, J. \& Penaluna, K. 2010. Creativity-Based Assessment and Neural Understandings: A Discussion and Case Study Analysis. Education \& Training, 52(8-9), p. 660. doi:10.1108/00400911011088971

Tour, J. 2012. Genesis of creativity. ACS Nano, 6(5), pp. 3649-3654. doi:10.1021/nn301299x

Wei, X., Weng, D., Liu, Y. \& Wang, Y. 2015. Teaching based on augmented reality for a technical creative design course. Computers \& Education, 81, pp. 221-234. doi:10.1016/j.compedu.2014.10.017

Wu, H., Lee, S. W., Chang, H. \& Liang, J. 2013. Current status, opportunities and challenges of augmented reality in education. Computers \& Education, 62(C), pp. 41-49. doi:10.1016/j.compedu.2012.10.024 